\title{
PENGEMBANGAN MULTIMEDIA PEMBELAJARAN INTERAKTIF MENGENAL ANGKA DAN HURUF UNTUK ANAK USIA DINI
}

\author{
Lovandri Dwanda Putra, Ishartiwi \\ PPs UNY, Fakultas Ilmu Pendidikan UNY \\ lovandridp@gmail.com, buisyk@yahoo.com
}

\begin{abstract}
Abstrak
Penelitian ini bertujuan untuk menghasilkan produk multimedia pembelajaran Mengenal Angka dan Huruf untuk Anak Usia Dini yang layak ditinjau dari aspek materi, aspek pembelajaran, aspek tampilan dan aspek pemrograman. Penelitian ini dilaksanakan di TK Aisyiyah Bustanul Athfal, Pringwulung, Yogyakarta dengan menggunakan metode penelitian dan pengembangan (R\&D). Model pengembangan yang digunakan dalam penelitian ini adalah model Lee dan Owens. Tahapan dalam penelitian ini terdiri dari: (1) tahap perencanaan, (2) tahap desain dan (3) tahap pengembangan. Hasil penelitian menunjukkan: produk multimedia yang dihasilkan adalah multimedia pembelajaran mengenal angka (1-10) dan huruf (A-Z) untuk anak usia dini, produk multimedia yang dihasilkan layak sebagai media pembelajaran mengenal angka dan huruf berdasarkan validasi oleh ahli materi dan ahli media. Kelayakan produk berdasarkan validasi ahli materi dengan hasil penilaian sangat baik $(4,66)$, validasi oleh ahli media dengan hasil penilaian sangat baik (5) dan penilaian oleh anak pada uji coba satu-satu, uji coba kelompok kecil dan uji coba operasional dengan hasil sangat baik, hal ini dibuktikan dengan rerata masingmasing aspek yang dicapai adalah di atas $81 \%$. Hasil penilaian oleh anak mencakup aspek kemenarikan, kemudahan dan kejelasan petunjuk materi.
\end{abstract}

Kata Kunci: Multimedia, Anak Usia Dini, Angka dan Huruf

\section{DEVELOPING INTERACTIVE MULTIMEDIA IN LEARNING NUMBERS AND LETTERS AMONG EARLY CHILDHOOD}

Lovandri Dwanda Putra, Ishartiwi

PPs UNY, Fakultas Ilmu Pendidikan UNY

lovandridp@gmail.com, buisyk@yahoo.com

\begin{abstract}
This research aims to produce interactive multimedia in learning Numbers and Letters among Early Childhood in terms of aspects of the material, learning aspects, aspects of the display and programming aspects. This research was conducted in Kindergarten Aisyiyah Bustanul Atfal, Pringwulung, Yogyakarta by using the method of research and development $(R \mathcal{E} D)$. The developing model is using Lee and Owens. Stages in this study consisted of: (1) planning, (2) design and (3) development. The results show the resulted product is a multimedia learning to recognize numbers and letters for early childhood, multimedia products produced viable as a medium of learning recognize numbers and letters based on validation by matter experts and media experts. Feasibility of products based validation matter experts with excellent assessment results (4.66), validation by expert assessment of media with very good results (5) and assessment by a child on a trial-one, small group testing and operational test with results very good, this is evidenced by the mean of each aspect wich achieved above $81 \%$. The results of the assessment by the child include aspects of the attractiveness, convenience and clarity of instructions material.
\end{abstract}

Keywords: Multimedia, Early Childhood, Numbers and Letters 


\section{Pendahuluan}

Pendidikan anak usia dini merupakan cabang khusus pendidikan yang berhubungan dengan anak-anak sejak lahir sampai delapan tahun. Undang-undang Nomor 20 Tahun 2003 tentang Sistem Pendidikan Nasional Pasal 1 angka 14 menyatakan bahwa Pendidikan Anak Usia Dini (PAUD) adalah suatu upaya pembinaan yang ditujukan kepada anak sejak lahir sampai dengan usia enam tahun yang dilakukan melalui pemberian rangsangan pendidikan untuk membantu pertumbuhan dan perkembangan jasmani dan rohani agar anak memiliki kesiapan dalam memasuki pendidikan lebih lanjut, yaitu sekolah dasar. Kemampuan dasar perkembangan pada anak saling mendukung satu sama lain. Salah satu kemampuan dasar yaitu kemampuan kognitif yang memegang peranan penting dalam kehidupan anak baik sekarang maupun pada masa yang akan datang.

Standar tingkat pencapaian perkembangan anak yang dinyatakan oleh permendiknas 58 tahun 2009 di lingkup perkembangan kognitif untuk anak usia 35 tahun, pada konsep bilangan, lambang bilangan 1-10 dan huruf, yaitu menyebutkan bilangan, mengenal konsep bilangan, mengenal lambang bilangan dan mengenal lambang huruf. Pembelajaran mengenal angka dan huruf yang berlangsung selama ini menggunakan metode pembelajaran yang berpusat pada guru dan kurangnya pemanfaatan media dalam pembelajaran mengenal angka dan huruf menjadikan anak kurang aktif dalam pembelajaran dan kurang memperhatikan dalam belajar.

Pesatnya perkembangan zaman dan kemajuan teknologi memberi kemudahan seseorang dalam mengemas dan menyajikan informasi, demikian pula dalam proses belajar mengajar. Pemanfaatan media dalam pembelajaran dapat membangkitkan keinginan peminat baru, meningkatkan motivasi dan rangsangan kegiatan belajar, dan bahkan berpengaruh secara psikologis kepada anak (Hamalik, 1986, p.24). Bahkan
Penelitian Jared Keengwe dan Grace onchwari, $(2009$, p.217) dalam journal technology and early childhood education, "A technology interaction profeesional development model for practicing teachers", menyatakan bahwa teknologi akan terus menjadi bagian integral dari ruangan kelas dan kehidupan seharihari. Menggunakan teknologi membantu anak usia dini untuk berkomunikasi, praktek keterampilan hidup dan lebih memahami konsep.

Salah satu produk teknologi yang dapat digunakan sebagai inovasi dalam pembelajaran adalah komputer. Hal tersebut sesuai dengan pernyataan Herman Dwi Surjono (1995, p.2) bahwa komputer sebagai salah satu produk teknologi dinilai tepat digunakan sebagai alat bantu pengajaran. Menurut Malik \& Agarwal (2012, p.470), multimedia used in right direction has also succeeded in psychomotor development and strengthening of visual processing of the intended users. Artinya multimedia yang digunakan pada arah yang benar juga menyukseskan perkembangan psikomotorik dan memperkuat proses visual para pemakai. Dipilihnya multimedia sebagai media yang dapat membantu anak mengenal angka dan huruf karena dapat menyatukan beberapa unsur media untuk menyampaikan materi seperti yang dikemukakan oleh Ivers \& Barron (2010, p.2) multimedia is the use of several media to present information, combinations may include text, graphics, animation, pictures and sound. Menurut pendapat tersebut, unsur multimedia yang terdiri dari teks, grafik, animasi, gambar, dan suara dalam pembelajaran diharapkan dapat memenuhi kebutuhan belajar anak yang memiliki kemampuan kognitif yang berbeda.

Multimedia pembelajaran interaktif memiliki menu-menu khusus yang dapat diakses oleh user (anak TK) untuk memunculkan informasi berupa audio, visual maupun fitur lain yang diinginkan oleh pengguna. Multimedia ini dapat digunakan menggunakan komputer. Dengan menggunakan media ini, peneliti ingin memperkenalkan kepada anak cara belajar 
menggunakan media pembelajaran interaktif melalui komputer yang dilengkapi dengan animasi, audio visual, fungsi tombol. Sehingga media belajar ini dapat menarik minat belajar anak dalam mengenal angka dan huruf. Diperlukan juga adanya dampingan dari orang tua maupun guru selama anak belajar menggunakan media belajar ini.

Pengembangan produk multimedia yang memenuhi aspek-aspek pembelajaran serta pemilihan media pembelajaran yang tepat guna dalam pembelajaran telah dibahas dalam salah satu bidang ilmu yaitu bidang instructional technology. Definisi Teknologi Pembelajaran yang dirumuskan oleh Association for Educational Communications And Technology (AECT) (2004, p.3) "Educational technology is the study and ethical practice of facilitating learning and improving performance by creating, using, and managing appropriate technological processes and resources". Definisi teknologi pembelajaran tahun 2004 ini mengandung maksud bahwa teknologi pembelajaran mempunyai peran untuk memfasilitasi pembelajaran dan meningkatkan kinerja dengan cara menciptakan, menggunakan atau memanfaatkan dan mengelola proses dan sumbersumber teknologi yang tepat.

Salah satu bidang garapan dalam Teknologi Pembelajaran yaitu menciptakan bahan ajar yang tepat guna sesuai dengan kebutuhan. Dalam kaitannya dengan pengembangan produk multimedia pembelajaran berdasarkan definisi di atas, peran teknologi pembelajaran adalah untuk memfasilitasi dan meningkatkan kinerja agar tujuan pembelajaran dapat tercapai dengan cara "creating, using, and managing" yaitu dengan menciptakan, menggunakan dan mengontrol bahan ajar yang dikembangkan agar sesuai dengan fungsinya dan dapat memberi kemudahan dalam belajar.

Berdasarkan bidang garapan teknologi pembelajaran di atas, maka cakupan Teknologi Pembelajaran salah satunya adalah menciptakan atau mengembangkan, menggunakan serta mengontrol bahan ajar yang tepat guna sesuai dengan kebutuhan siswa. Dalam pembelajaran di sekolah, guru hendaknya selalu berinovasi dalam menciptakan pembelajaran yang inovatif melalui pengembangan bahan ajar sebagai media yang dapat digunakan dalam proses pembelajaran. Upaya pengembangan bahan ajar sebagai media dalam proses pembelajaran penting untuk dilakukan guna mewujudkan pembelajaran yang efektif dan efisien. Sehingga kompetensi yang harus dicapai oleh anak dapat dikuasai.

Berdasarkan latar belakang masalah, maka rumusan masalah yang dapat dikemukakan dalam penelitian ini yaaitu: bagaimana menghasikan multimedia pembelajaran interaktif dengan materi mengenal angka (1-10) dan huruf (A-Z) yang layak digunakan dalam proses pembelajaran anak usia dini, ditinjau dari aspek materi, aspek pembelajaran, aspek tampilan dan aspek pemrograman. Sedangkan tujuan dari penelitian ini yaitu untuk menghasilkan produk multimedia pembelajaran interaktif mengenal angka dan huruf yang layak untuk anak usia dini.

\section{Metode Penelitian}

Pengembangan produk multimedia pembelajaran dengan pendekatan komunikatif termasuk Research and Development ( $R$ \& D). Penelitian ini bertujuan untuk menghasilkan produk multimedia pembelajaran interaktif mengenal angka dan huruf untuk anak usia dini

Model pengembangan dalam penelitian ini sesuai dengan yang dikemukakan oleh William W. Lee \& Diana L. Owens (2004, p.3) yang terdiri atas empat tahapan: (1) analisis kebutuhan, (2) desain pembelajaran, (3) produksi/pengembangan media, dan (4) evaluasi.

Prosedur pengembangan produk multimedia pembelajaran dalam penelitian ini dapat dijelaskan sebagaimana terdapat dalam gambar berikut. 


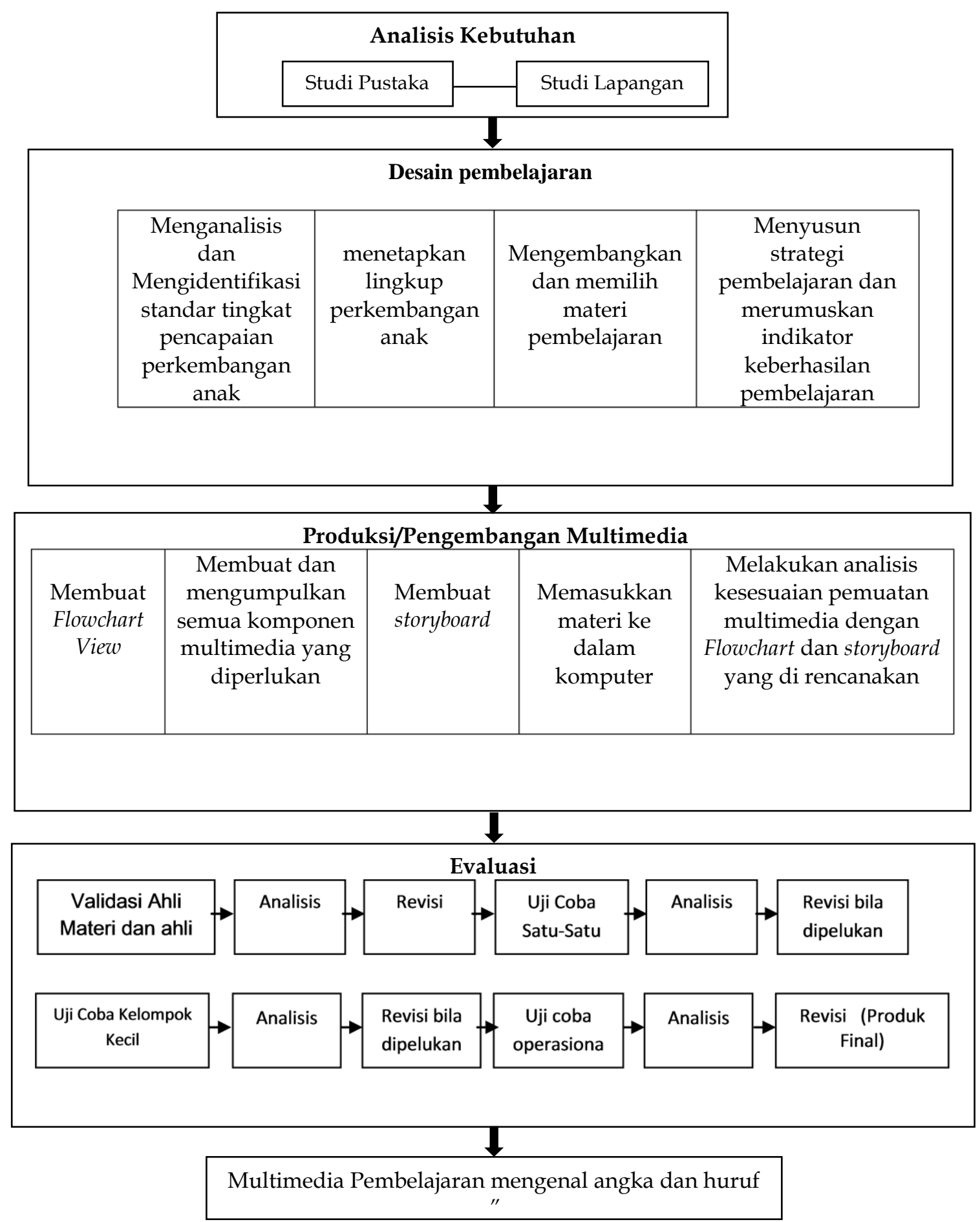

Gambar 1. Prosedur Pengembangan Multimedia Interaktif Mengenal Angka dan Huruf untuk Anak Usia Dini

Desain Uji Coba

Uji coba produk dilakukan untuk mendapatkan data yang digunakan untuk mengetahui kelemahan produk yang dikembangkan sebagai dasar untuk melakukan revisi produk multimedia.
Tahap awal uji coba adalah, Produk awal multimedia mengenal angka dan huruf diuji coba oleh dua orang ahli, yaitu ahli materi dan ahli media. Selanjutnya hasil uji coba para ahli dianalisis dan dijadikan masukan untuk perbaikan produk. 
Setelah revisi produk selesai, produk diuji coba pada anak, hal ini untuk mengetahui tanggapan atau kesan anak terhadap multimedia mengenal angka dan huruf, uji coba pada anak meliputi uji coba satu lawan satu, kelompok kecil dan operasional. Hasil uji coba pada anak ini kemudian dianalisis dan dijadikan masukan untuk perbaikan produk ahir.

\section{Subjek Uji Coba}

Subjek uji coba dalam penelitian pengembangan ini adalah anak usia dini di TK Aisyiyah Bustanul Athfal priwulung, Yogyakarta yang berjumlah 24 orang anak. Teknik dan Instrumen Pengumpulan Data

Teknik yang dilakukan untuk menghimpun data selama proses pengembangan produk multimedia pembelajaran mengenal angka dan huruf ini adalah menggunakan teknik wawancara, angket, dan observasi. Instrumen yang digunakan untuk mengumpulkan data berupa instrumen penilaian untuk menilai produk yang telah dikembangkan dari aspek instruksional, aspek materi, aspek pemrograman, dan aspek tampilan. Instrumen diberikan kepada ahli materi dan ahli media. Sedangkan instrument untuk anak digunakan untuk mengetahui tanggapan anak tentang multimedia yang dikembangkan.

Wawancara dilakukan untuk mengumpulkan data dari anak dan guru sehubungan dengan analisis kebutuhan yang diperlukan sebagai pengembangan produk multimedia pembelajaran. sedangkan Angket digunakan untuk mengetahui ketepatan atau kelayakan rancangan produk sebagai program multimedia pembelajaran dari ahli materi, ahli media. Angket ini digunakan untuk pengumpulan data kuantitatif. Instrumen diberikan kepada ahli materi untuk mendapatkan data tentang kelayakan program yang dikembangkan ditinjau dari aspek pembelajaran dan aspek isi materi. Hasil dari penilaian dijadikan sebagai dasar untuk melaksanakan revisi produk multimedia pembelajaran.
Instrumen selanjutnya diberikan kepada ahli media untuk mendapatkan data tentang kelayakan program yang dikembangkan ditinjau dari aspek tampilan dan aspek pemograman. Hasil dari penilaian tersebut dijadikan bahan untuk merevisi dan penyempurnaan produk pengembangan. lembar evaluasi menggunakan skala interval 5 dengan jenis pertanyaan yang sesuai dengan masing-masing posisi sebagai penilai

Instrumen angket berikutnya diberikan kepada anak untuk memperoleh data tentang tanggapan anak terhadap program yang dihasilkan dilihat dari sudut pandang anak ketika melakukan uji produk. Angket untuk anak menggunakan skala Guttman, skala pengukuran dengan tipe ini akan didapat jawaban yang tegas, yaitu "sukatidak"; "benar-salah"; "mudah-sulit"; "positif-negatif". Jawaban dari anak dibuat skor tertinggi "satu" dan skor terendah "nol".

\section{Validitas Instrumen}

Validitas instrumen dalam penelitian berupa pembuatan kisi-kisi kuesioner/ angket untuk ahli materi, ahli media, dan anak/pengguna, diberikan kepada seorang dosen ahli pembelajaran yang ditunjuk sebagai validator untuk memvalidasi instrumen, kemudian hasil dari validasi tersebut dianalisis dan dilakukan perbaikan jika terdapat kesalahan dalam penyusunan instrumen. Setelah instrumen tersebut dinyatakan valid oleh validator selanjutnya instrumen dapat digunakan untuk melakukan penelitian

\section{Teknik Analisis Data}

Teknik analisis data kelayakan produk multimedia pembelajaran menggunakan skala Likert. Skor yang diperoleh kemudian dikonversikan menjadi nilai dengan skala 5, yaitu membagi nilai standar menjadi lima skala atau lima kualifikasi. Skala 5 dalam teknik statistik penelitian dan pengembangan ini yaitu sangat baik (5), baik (4), cukup baik (3), kurang baik 
(2), dan sangat kurang baik (1). Apabila ahli media dan ahli materi memberikan tanggapan "sangat baik" pada butir pertanyaan, maka skor butir pertanyaan tersebut sebesar " 5 " dan seterusnya. Adapun acuan pengubahan skor menjadi skala lima disajikan pada Tabel 1.

Tabel 1. Konversi skor pada skala 5.

\begin{tabular}{ccc}
\hline Nilai & Interval & Data Kualitatif \\
\hline 5 & $\mathrm{X}>\mathrm{Xi}+1,80 \mathrm{Sbi}$ & Sangat baik \\
4 & $\mathrm{Xi}+0,60 \mathrm{Sbi}<\mathrm{X} \leq \mathrm{Xi}+1,80 \mathrm{Sbi}$ & Baik \\
3 & $\mathrm{Xi}-0,60 \mathrm{Sbi}<\mathrm{X} \leq \mathrm{Xi}+0,60 \mathrm{Sbi}$ & Cukup \\
2 & $\mathrm{Xi}-1,80 \mathrm{Sbi}<\mathrm{X} \leq \mathrm{Xi}-0,60 \mathrm{Sbi}$ & Kurang \\
1 & $\mathrm{X} \leq \mathrm{Xi}-1,80 \mathrm{Sbi}$ & Sangat kurang \\
\hline
\end{tabular}

Sedangkan teknik analisis data angket untuk anak menggunakan skala Guttman dan persentase jawaban anak. Persentase untuk setiap kemungkinan jawaban diperoleh dari membagi frekuensi dengan jumlah subjek uji coba, kemudian dikalikan $100 \%$. Adapun rumusnya adalah sebagai berikut:

$$
\text { Persentase jawaban }=\mathrm{f} / \mathrm{N} \times 100
$$

Keterangan:

$\mathrm{f}=$ frekuensi subjek uji coba yang dimiliki alternatif jawaban.

$\mathrm{N}=$ jumlah seluruh objek uji coba

Selanjutnya persentase yang diperoleh diterjemahkan kedalam kategori yang disajikan pada Tabel 2.

Tabel 2. Konversi Data Kuantitatif ke Data Kualitatif dengan Skala Guttman

\begin{tabular}{|c|c|}
\hline $\begin{array}{l}\text { Tingkat } \\
\text { Kelayakan }\end{array}$ & Klasifikasi Penilaian \\
\hline $81 \%-100 \%$ & $\begin{array}{l}\text { Sangat baik/Sangat } \\
\text { benar/Sangat jelas }\end{array}$ \\
\hline $66 \%-80 \%$ & Baik/Sesuai/Setuju/Jelas \\
\hline $56 \%-65 \%$ & $\begin{array}{l}\text { Kurang baik/kurang } \\
\text { Sesuai/Kurang Setuju }\end{array}$ \\
\hline$<55 \%$ & $\begin{array}{l}\text { Sangat kurang baik/Sangat } \\
\text { Kurang Setuju }\end{array}$ \\
\hline
\end{tabular}

\section{Hasil Penelitian}

Pengembangan produk multimedia pembelajaran dengan pendekatan komunikatif ini dikembangkan melalui tahap perencanaan penelitian. Perencanaan penelitian yang dilakukan adalah studi pustaka dan studi lapangan. pada tahap studi pustaka, data yang diperoleh dari kegiatan pengumpulan informasi ini adalah sebagai berikut.

Pertama, standar tingkat pencapaian perkembangan anak dalam lingkup perkembangan konsep bilangan, lambang bilangan dan huruf ada-lah anak mengetahui konsep banyak dan sedikit, mampu membilang banyak benda satu sampai sepuluh, mengenal konsep lambang bilangan, mengenal lambang bilangan dan mengenal lambang huruf. Data diperoleh dari Permendiknas no 58 tahun 2009 tentang Standar Tingkat Pencapaian Perkembangan Anak Usia Dini.

Kedua, penggunaan multimedia pembelajaran mempunyai dampak yang sangat baik terhadap proses dan hasil belajar, multimedia pembelajaran sangat membantu siswa dalam memahami konsep materi secara konkret sehingga tidak abstrak. Ketiga, penggunaan komputer yang sangat bermanfaat dalam pembelajaran.

Pada tahap studi lapangan, data yang diperoleh berdasarkan observasi dan wawancara terhadap kepala TK dan anak kelompok kelas A yaitu: (1) media pembelajaran yang digunakan untuk pembelajaran adalah media sederhana yang ada di sekolah, seperti papan tulis, kertas gambar, dan benda-benda di sekitar sekolah; (2) reaksi anak dalam belajar bermacam-macam berdasarkan minat dan pengetahuan mereka. Bagi anak yang memahami apa yang dijelaskan, mereka akan aktif bertanya dan antusias untuk belajar, bagi anak yang kurang berminat mereka akan melakukan aktifitas lain yang tidak ada hubungannya dalam pembelajaran; (3) hasil belajar anak bervariasi, ada yang telah mencapai standar tingkat perkembangan namun juga banyak yang belum; (4) ba- 
nyak anak kesulitan dalam memahami konsep angka dan huruf, hal ini terjadi karena anak sulit membedakan konsep-konsep setiap angka dan bentuk-bentuk huruf; (5) sekolah sudah mempunyai fasilitas media pembelajaran seperti LCD proyektor dan speaker aktif. tetapi pemanfaatannya masih kurang, seperti LCD biasanya digunakan untuk kegiatan menonton film kartun atau video musik anak-anak; (6) guruguru sudah biasa mengoperasikan komputer atau laptop dalam kegiatan sehari-hari; (7) dari 24 orang anak yang diwawancarai, 20 anak memiliki komputer atau laptop dirumah dan biasa menggunakannya untuk bermain game dan belajar, sedangkan 5 orang anak lainnya tidak mempunyai komputer atau laptop, tetapi pernah menggunakannya untuk bermain game dan belajar.

Hasil data yang diperoleh dari studi pustaka dan studi lapangan selanjutnya dijadikan bahan pertimbangan dan masukan untuk mendesain serta mengembangkan produk multimedia pembelajaran mengenal angka dan huruf. Multimedia pembelajaran yang dihasilkan dalam penelitian dikembangkan dengan menggunakan software Adobe Flash CS3 dan didukung oleh program Adobe Ilustrator CS3 untuk membuat gambar atau ilustrasi benda-benda dan binatang, serta program Adobe Audition 1.5 untuk merekam suara sebagai narasi dalam menjelaskan petunjuk dan cara belajar menggunakan program multimedia mengenal angka dan huruf yang dikembangkan peneliti.

Multimedia hasil pengembangan ini secara umum terdiri atas: (a) halaman pembuka yang berisi judul multimedia, yaitu: mengenal angka dan huruf untuk anak usia dini; (b) pendahuluan berisi keterangan singkat tentang isi multimedia; (c) menu utama terdiri dari dua menu pokok, yaitu: mengenal angka dan mengenal huruf; (d) isi materi dari multimedia ini adalah teks, suara dan gambar yang menjelaskan tentang pengenalan angka (1-10) dan huruf (A-Z); (e) games memasangkan angka (1-10) dan tebak huruf (A-Z). Menu game ini berfungsi untuk hiburan bagi anak dan juga sebagai pengulangan dari materimateri yang dipelajari oleh anak yang disajikan dalam bentuk permainan yang menyenangkan; (f) profil pengembang berisi identitas pengembang multimedia.

\section{Hasil Validasi Ahli Materi}

Pelaksanaan validasi dengan cara memberikan produk hasil pengembangan kepada validator untuk menilai masingmasing aspek serta memberikan penilaian dengan cara mengisi angket skala 5 yang telah disediakan. Pada proses validasi, peneliti memperoleh data kuantitatif dan kualitatif yang sangat mendukung untuk pengembangan dan penyempurnaan produk multimedia pembelajaran yang dikembangkan.

Validasi ahli materi dilakukan untuk mengetahui kualitas produk multimedia pembelajaran ditinjau dari aspek materi. Aspek yang dinilai meliputi aspek pembelajaran dengan jumlah butir penilaian sebanyak 12 butir dan aspek isi/materi sebanyak 8 butir. Hasil penilaian ahli materi dapat dilihat pada Tabel 3 berikut.

Tabel 3. Rerata Skor Hasil Validasi Ahli Materi

\begin{tabular}{clrl}
\hline No & Aspek Penilaian & Skor & Kriteria \\
\hline 1 & Isi Materi & 4,75 & Sangat baik \\
2 & Pembelajaran & 4,58 & Sangat baik \\
& Jumlah & 9,33 & \\
& Rata-rata & 4,66 & Sangat baik \\
\hline
\end{tabular}

Hasil Validasi Ahli Media

Validasi dilakukan untuk mengetahui kualitas bahan ajar ditinjau dari aspek media. Dua aspek yang dinilai yaitu aspek tampilan dengan jumlah butir penilaian sebanyak 18 butir dan aspek pemograman atau kegrafisan sebanyak 10 butir. Penilaian dengan menggunakan angket skala 5. Hasil penilaian ahli media dapat dilihat pada Tabel 4. 
Tabel 4. Rekap Rerata Skor Hasil Validasi Ahli Media

\begin{tabular}{cccc}
\hline No & Aspek penilaian & Skor & Kriteria \\
\hline 1 & Aspek Tampilan & 5 & Sangat baik \\
2 & Aspek Pemograman & 5 & Sangat baik \\
& Jumlah & 10 & \\
& Rata-rata & 5 & Sangat baik \\
\hline
\end{tabular}

Hasil Uji Coba Satu Lawan Satu

Uji coba satu lawan satu dilaksanakan untuk mendapatkan bukti-bukti empiris mengenai kelayakan multimedia pembelajaran mengenal angka dan huruf yang dikembangkan dalam mengidentifikasi kesalahan-kesalahan dan mendapatkan saran dan komentar untuk melakukan revisi terhadap produk. Data yang diperoleh dari hasil tanggapan anak terhadap produk multimedia pembelajaran yang dikembangkan kemudian dikonversikan ke dalam skala Guttman. Uji coba dilakukan dengan menunjukkan produk dan menjelaskan secara singkat aplikasi penggunaan multimedia pembelajaran mengenal angka dan huruf kepada anak kemudian anak memberikan tanggapan mengenai kualitas produk dari segi kemudahan, kemenarikan, dan kejelasan narasi atau petunjuk. Rerata hasil tanggapan anak pada ujicoba satu-satu adalah 100\% dengan kategori "sangat baik". Terdapat 3 aspek penilaian yang dapat dinilai oleh anak. semua aspek dinilai dengan kategori "sangat baik".

Secara visual tampilan keseluruhan penilaian anak pada ujicoba satu lawan satu terhadap multimedia pembelajaran mengenal angka dan huruf yang dikembangkan disajikan pada Gambar 2.

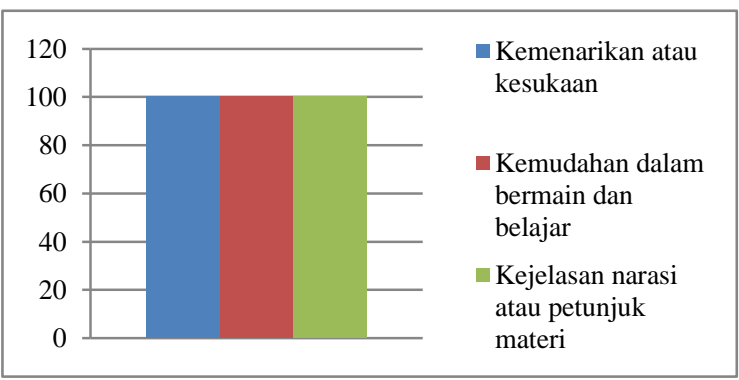

Gambar 2. Diagram Hasil Penilaian Anak pada Uji Coba Satu-Satu
Hasil Uji Coba Kelompok Kecil

Uji coba dilakukan dengan menunjukkan produk dan menjelaskan secara singkat aplikasi penggunaan multimedia pembelajaran mengenal angka dan huruf kepada anak kemudian anak memberikan tanggapan mengenai kualitas produk dari segi kemudahan, kemenarikan dan kejelasan narasi atau petunjuk. Rerata hasil tanggapan anak pada uji coba kelompok kecil adalah 100\% dengan kategori "sangat baik". Terdapat 3 aspek penilaian yang dapat dinilai oleh anak. Semua aspek dinilai dengan kategori "sangat baik". Secara visual tampilan keseluruhan penilaian anak pada uji coba kelompok kecil terhadap multimedia pembelajaran mengenal angka dan huruf yang dikembangkan disasjikan pada Gambar 2.

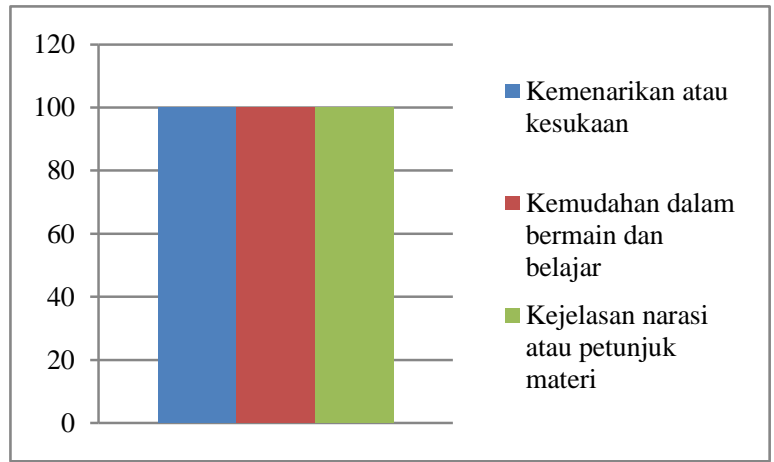

Gambar 3. Diagram hasil penilaian anak pada uji coba kelompok kecil

\section{Hasil Uji Coba Operasional}

Pada uji caba operasional diketahui bahwa salah satu aspek yaitu aspek kemudahan dalam bermain dalam belajar mendapatkan nilai $94 \%$ yang berarti ada 2 anak yang menjawab "sulit" untuk aspek ini. Sementara itu hasil tanggapan anak pada dua aspek lainnya adalah $100 \%$ dengan kategori "sangat baik". Secara visual tampilan keseluruhan penilaian anak pada uji coba operasional terhadap multimedia pembelajaran mengenal angka dan huruf yang dikembangkan disajikan pada Gambar 4 .

Bentuk akhir dari produk multimedia pembelajaran yang dikembangkan ini adalah software yang dikemas dalam ben- 
tuk CD pembelajaran interaktif. Multimedia pembelajaran yang dihasilkan dalam penelitian dikembangkan dengan menggunakan software Adobe Flash CS3 dan didukung oleh program Adobe Ilustrator CS3 untuk membuat gambar atau ilustrasi benda-benda dan binatang, serta program Adobe Audition 1.5 untuk merekam suara sebagai narasi dalam menjelaskan petunjuk dan cara belajar menggunakan program multimedia mengenal angka dan huruf yang dikembangkan peneliti.

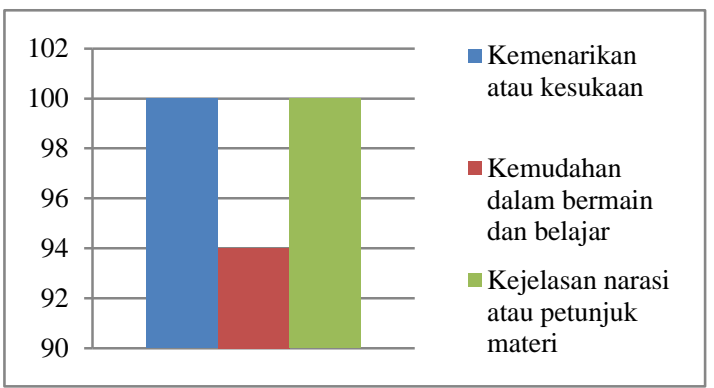

Gambar 4. Diagram Hasil Penilaian anak pada Uji Coba operasional

Produk ini memuat 2 pokok menu materi yaitu materi mengenal angka dan materi mengenal huruf yang di dalamnya dilengkapi dengan teks, audio, gambar dan animasi. Adapun komponen-komponen dari program multimedia pembelajaran mengenal angka dan huruf ini antara lain: halaman pembuka, pendahuluan, menu utama, materi, games, dan profil pengembang. program multimedia ini ditujukan pada anak usia dini kelompok A yang berusia 4-5 tahun.

Proses pengembangan produk multimedia ini mengikuti tahap-tahap dalam pengembangan dan juga telah selesai divalidasi yang dilakukan oleh dua orang validator ahli yang terdiri atas 1 orang ahli materi dan 1 orang ahli media, Uji coba yang terdiri atas tiga tahap yaitu uji coba satu-satu, uji coba kelompok kecil dan uji coba operasional dengan jumlah subjek 24 anak usia dini.

Berdasarkan hasil penilaian yang dilakukan oleh ahli materi terhadap kualitas produk ditinjau dari aspek materi dan aspek pembelajaran mendapatkan rerata skor 4,45 dengan kategori "sangat baik". Sedangkan hasil penilaian yang dilakukan oleh ahli media terhadap kualitas multimedia pembelajaran yang dikembangkan ditinjau dari aspek tampilan dan aspek pemrograman dengan rerata skor 4,34 kategori "sangat baik". Maka dapat disimpulkan bahwa multimedia pembelajaran mengenal angka dan huruf yang dikembangkan dalam penelitian ini termasuk dalam kategori sangat baik sehingga multimedia yang dikembangkan ini layak untuk digunakan sebagai sumber belajar.

Karakteristik dari program multimedia pembelajaran mengenal angka dan huruf hasil pengembangan ini memiliki beberapa kelebihan. Kelebihan tersebut antara lain: (1) dalam penyajian terdapat penggabungan berbagai unsur multimedia (teks, gambar, suara, animasi, dan interaktivitas) yang membantu anak untuk aktif mengkonstruksi pengetahuannya sendiri, pemahaman mereka, (2) file multimedia ini berbentuk aplikasi (*.exe), sehingga dapat langsung dioperasikan tanpa menginstal software apa pun, (3) terdapat feedback/ umpan balik di dalamnya, (4) multimedia pembelajaran ini membantu guru dalam menjelaskan konsep angka dan huruf.

Selama proses penelitian data tanggapan, saran dan komentar guru pendamping mengenai multimedia pembelajaran mengenal angka dan huruf ini memiliki kelebihan antara lain, gambar-gambar dan sajian animasi media sangat menarik, sehingga memudahkan anak untuk mengingat materi dan tidak takut untuk mencoba program multimedia, tampilan materi sudah mampu mengurutkan alur berpikir anak, keurutan sudah terpenuhi, sehingga belajar menjadi mudah, anak terlihat sangat antusias mengikuti pembelajaran dengan multimedia ini, permainan sangat bagus dan sesuai dengan perkembangan anak, anak-anak sangat senang belajar dan secara umum tidak ada kesulitan, hanya untuk awal penggunaan multimedia anak harus didampingi 


\section{Simpulan dan Saran}

Simpulan

Berdasarkan hasil penelitian dan pengembangan produk multimedia pembelajaran mengenal angka dan huruf, maka disimpulkan bahwa: Multimedia hasil pengembangan ini layak digunakan dalam pembelajaran dibuktikan berdasarkan hasil validasi ahli materi dari aspek materi dan aspek pembelajaran mendapatkan rerata skor 4,45 dengan kategori "sangat baik". Sedangkan hasil penilaian yang dilakukan oleh ahli media terhadap kualitas multimedia pembelajaran yang dikembangkan ditinjau dari aspek tampilan dan aspek pemrograman dengan rerata skor 4,34 kategori "sangat baik". dan hasil uji coba kepada anak usia dini terhadap kelayakan multimedia pembelajaran mengenal angka dan huruf adalah "sangat baik". Hal ini berdasarkan perolehan skor rerata di atas $81 \%$ pada setiap aspek penilaian untuk anak. Multimedia ini dapat digunakan dalam pembelajaran baik secara klasikal maupun individual dan untuk awal penggunaan produk anak sebaiknya didampingi.

\section{Saran}

Saran pemanfaatan bagi anak hendaknya dapat memanfaatkan multimedia pembelajaran mengenal angka dan huruf dengan belajar secara berulang-ulang, $\mathrm{Hal}$ ini dimaksudkan untuk memperjelas pemahaman anak tentang konsep angka dan huruf. Sedangkan bagi guru hendaknya mendampingi anak dalam pemanfaatan multimedia ini, guru dapat menjelaskan cara bermain dan menggunakan multimedia pada saat penggunaan multimedia mengenal angka dan huruf yang pertama kali.

\section{Daftar Pustaka}

AECT. (2004). AECT definition and terminology committee document: the meanings of educational technology.

Alessi, S.M \& Trollip, S.R. (2001). Multimedia for learning method and development. Needham Heights: Allyn \& Bacon.

Hamalik ( 1986 ) "Media Pembelajaran". Bandung: Allumni.

Ivers, K.S \& Barron, A.E. (2010). Multimedia project in education designing, producing and assessing. California: Libraries Unlimited.

Jared Keengwe \& Grace Onchwari. (2009). A technology interaction profeesional development model for practicing teachers. Journal technology and early childhood education (37:209218)

Ivers, K.S \& Barron, A.E. (2010). Multimedia project in education designing, producing and assessing. California: Libraries Unlimited.

Lee, W. W. \& Owens, D. L. 2004. Multimedia-based instructional design: Computer-based training, web-based training, distance broadcast training, performance based solution (2nd ed). San Francisco, USA: Pfeiffer A Wiley Imprint.

Permendiknas No 58 Tahun 2009. Standar Tingkat Pencapaian Perkembangan Anak Usia Dini.

S. Malik \& A. Agarwal (2012). Use of multimedia as a new educational technology tool-a study. International Journal of Information and Education Technology, Vol. 2, No. 5, October 2012. 